\title{
СПРОБА АНАЛІЗУ ЗАЦІКАВЛЕНОСТІ ВЧЕНИХ І ДОСЛІДНИКІВ У ВСЕБІЧНОМУ РОЗВИТКУ МАЙБУТНІХ І ПРАКТИКУЮЧИХ УЧИТЕЛІВ ІНФОРМАТИКИ
}

\author{
Олена Федоренко \\ кандидат педагогічних наук, доцент кафедри \\ методики навчання математики та методики навчання інформатики, \\ ДВНЗ «Донбаський державний педагогічний університет» \\ м. Слов'янськ, Донецька область, Україна \\ http://orcid.org/0000-0002-1897-874X \\ fedorenko.elena1209@gmail.com \\ Ганна Зима \\ учитель інформатики I категорії \\ заступник директора з науково-методичної роботи \\ Райгородоцька ЗОШ I-III ступенів \\ Донецька область, Слов'янський район, смт Райгородок, \\ http://orcid.org/0000-0002-0525-6553 \\ raygorodokuspih@i.ua
}

Анотація. Стаття присвячена аналізу проблеми всебічного розвитку майбутніх i практикуючих учителів інформатики. Аналізуючи роботи сучасних учених і дослідників було виявлено значну кількість розглянутих проблем і розроблених ними методик та методичних рекомендацій, пов'язаних із всебічним розвитком майбутніх і практикуючих учителів інформатики. Позитивним і прогресивним моментом $\epsilon$ те, що для всебічного розвитку майбутніх і практикуючих учителів інформатики розроблено чимало методик і методичних рекомендацій, пов'язаних із підвищенням різноманітних компетенцій і компетентностей, заснованих на інформаційно-комунікаційних технологіях i сучасному програмному забезпеченні як пропрієтарному, так і вільному. Підкреслено, що інформаційно-комунікаційні технології є базисом розвитку особистості з професійного погляду, вони є основою розвитку індивідуальних, творчих здібностей та особистих якостей таких, як саморозвиток та самореалізація.

Ключові слова: компетенція; компетентність; майбутні вчителі інформатики; практикуючі вчителі інформатики, пропрієтарне програмне забезпечення; вільне програмне забезпечення.

Постановка проблеми в загальному вигляді. Наявність у сучасних студентів постійного бажання до самовдосконалення, оновлення власних знань i вмінь, розвитку всебічних компетенцій та компетентностей задля того, щоб бути конкурентоспроможним на ринку праці є головною метою сучасної освіти, заснованою на аспектах глобальної інформатизації суспільства. Зазначені якості зумовлені потребою в сучасних фахівцях із поглибленими знаннями, уміннями, навичками тощо. На сьогодні пріоритетним завданням розвитку сучасної вищої освіти є розробка нової освітньої парадигми, що несе в собі ідею навчити 
сучасних випускників вищої школи бути творцями та ініціаторами власного саморозвитку.

Навчити майбутніх учителів основам самооновлення знань та використання набутих навичок і вмінь у власній професійній діяльності $\epsilon$ головною складовою сучасної педагогіки і вчителів інформатики як майбутніх, так i практикуючих. Озброїти їх знаннями, уміннями, необхідними для саморозвитку в процесі подальшої освіти - одне 3 найважливіших завдань вищого закладу освіти [7]. Також до основних завдань вищої освіти належить організація процесу навчання, на базі якого майбутні вчителі, у нашому випадку вчителі інформатики, активно та із зацікавленням i захопленням будуть працювати [14, с. 13] у напрямі саморозвитку, убачаючи плоди власної роботи та практикуючи в собі постійну потребу розвитку компетентностей. Аналізуючи праці науковців і дослідників, ми бачимо, що окреслена проблема є актуальною.

Аналіз останніх досліджень і публікацій. Дослідженнями проблем організації самоосвітньої компетентності майбутніх і практикуючих учителів інформатики займались такі вчені, як Н. Балик, В. Биков, А. Гуржій, Л. Брескіна, М. Жалдак, М. Лапчик, Н. Морзе, С. Прийма, С. Раков , Ю. Рамський, С. Семеріков, Т. Тихонова, Ю. Триус, Г. Цибко, Г. Шугайло та ін.; інформатична компетентність учителів інформатики розглянута в роботах Н.Баловсяк, В. Беспалова, В. Болотова, М. Головань, М. Жалдака, Ю. Рамського, М. Рафальської, В. Серикова та ін.; інформаційно-комп'ютерна компетентність як компонент професійної підготовки вчителя інформатики досліджена П. Беспаловим, I. Захар, В. Котенко, Л. Сурменко та ін.; професійна компетентність - В. Биковим, Л. Білоусовою, М. Жалдак, Н. Морзе, С. Раковим, Я. Сікора, О. Спіріним, М. Лапчик, Г. Луньовою, Ю. Рамським, Т. Тихоновою та ін.; дослідницька компетентність М. Золочевською та ін.

Інформаційну компетентність було розглянуто Н. Баловсяк, М. Дзугоєвою, I. Срмаковим, О. Зайцевою, Н. Насировою, С. Трішиною, А. Хуторським та ін.; інформаційно-технологічну - Т. Тихоновою, Г. Луньовою та ін.; IKTкомпетентність - В. Акуленко, С. Раковим та ін.; інформаційно-комунікаційну компетентність - А. Гуржій, Н. Морзе, О. Овчарук та ін., а також багато інших компетенцій та компетентностей було розглянуто вченими та дослідниками щодо формування їх у майбутніх і практикуючих учителів інформатики.

Формулювання цілей статті (постановка завдання). У межах статті спробуємо проаналізувати стан зацікавленості та розробки сучасними науковцями і дослідниками різнобічного розвитку проблем і методик, а також методичних рекомендацій, пов'язаних iз широким розвитком майбутніх i практикуючих учителів інформатики.

Результати дослідження. Ринок праці сьогодення постійно змінює напрями та висуває все більш високі стандарти та вимоги до претендентів, i лише вміння самоорганізовуватися, самовдосконалюватися, самонавчатися тощо допоможе майбутнім спеціалістам стати фахівцями високого рівня в обраній 
галузі. Усі переліченні ознаки фахівця високого рівня є наслідком придбаних навичок під час навчання у ВНЗ та ті, що були спроектовані практикуючими вчителями інформатики на власну професійну діяльність.

Говорячи про розвиток самоосвітньої компетентності, маємо зазначити, що самоосвітня компетентність майбутніх учителів, у нашому випадку майбутніх учителів інформатики, є одним із головних компонентів досягнення професіоналізму як через загальнопедагогічну необхідність, так і через професійне спрямування [14, с. 17].

Тільки компетентні, високомобільні, самоорганізовані та ініціативні фахівці здатні оновлювати набуті знання й уміння, самовдосконалюватися як у професійному, так і в особистісному плані, які відповідають вимогам соціального замовлення суспільства $[14$, с. 14$]$. І. Зязюн у своїй роботі зазначив, що в порівняльному цілепокладанні важливішої, відповідальнішої, важчої служби в державі за учительську не існує [5, с. 292]. Саме тому, проблема сучасного стану всебічного розвитку різноманітних компетенцій та компетентностей майбутніх і практикуючих учителів інформатики є дуже актуальною та цікавою.

Т. Скоробогатова підкреслила неможливість професії вчителя інформатики без елемента самоосвіти. Самоосвіта вчителя інформатики - це цілеспрямована діяльність 3 удосконалення наявних i отримання нових психолого-педагогічних і методичних знань, метою якої є самовдосконалення в

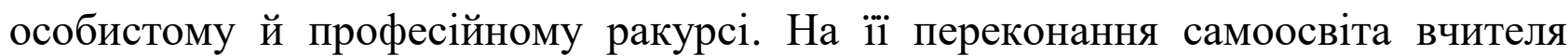
інформатики складається із таких компонентів, як інтегративна особистісна властивість, що забезпечується емоційно-ціннісним ставленням до саморозвитку й самоосвітньої діяльності [11].

Зокрема, проблемі навчання майбутніх учителів інформатики присвячено роботу С. Семерікова, у якій автор запропонував навчати майбутніх учителів за такою методикою, яка б давала їм знання, універсальні за своєю суттю, на основі чого майбутні вчителі інформатики могли б швидко змінити себе в новій сформованій обстановці [9, с. 21].

Вивчаючи проблему підготовки майбутніх учителів інформатики в педагогічному виші, О. Спірін запропонував на основі власного проведеного аналізу таку загальну структуру та орієнтовну класифікацію компетенцій учителя інформатики [13, с. 155]:

I. Загальні компетенції: індивідуальної ідентифікації та саморозвитку, міжособистісні, суспільно-системні.

II. Професійно-спеціалізовані компетениії:

- загальнопрофесійні;

- предметно-орієнтовані, або профільно-орієнтовані;

- технологічні;

- професійно-практичні.

ІКТ-компетентність учителя інформатики, за визначенням О. Спіріна, - це підтверджена здатність використовувати на практиці інформаційно- 
комунікаційні технології для задоволення власних індивідуальних потреб i розв'язування суспільно значущих, зокрема професійних, завдань у певній предметній галузі [12].

Соціально орієнтована підготовка майбутнього вчителя інформатики була розглянута В. Сергієнко та I. Войтович, які зазначили, що така підготовка буде ефективною за умов [10, с. 11]:

- формування знань і вмінь студентів щодо змісту позакласної та позашкільної діяльності;

- $\quad$ формування позитивної мотивації до діяльності на благо суспільства;

- урахування особливостей соціуму, у якому проживає вчитель;

- внесення додаткової інформації в економічні і професійно орієнтовані дисципліни та в зміст виробничих i педагогічних практик майбутнього вчителя інформатики в різних типах загальноосвітніх та позашкільних закладів;

- упровадження спеціальних курсів, удосконалення наявних тощо.

Учитель інформатики є провідником інформативних знань не лише до учнів, а й до їхніх батьків і рідних; перебуває в постійному творчому пошуку. Кваліфікацію вчителя інформатики визначають такі складові, як: інформаційна, комунікативна та проектна [4, с. 26, 30].

Інформаційна компетенція майбутнього вчителя інформатики - це інтегральна характеристика, що відображає наявність умінь розв'язувати різні проблеми і завдання, які виникають при використанні інформаційних технологій у педагогічній діяльності, із використанням знань, умінь здійснювати рефлексію та самоосвіта на засадах досвіду діяльності [15, с. 66].

Високий рівень інформаційно-комунікаційної компетентності (IКкомпетентності) вчителя інформатики стає запорукою ефективного використання інформаційно-комунікаційних технологій та $\epsilon$ одним iз найважливіших показників успішності його діяльності й одночасно необхідною передумовою для подальшого підвищення рівня його професійної компетентності [4, с. 21].

Інформаційно-комп'ютерна компетентність учителя інформатики - це системна властивість особистості, що характеризує іiі глибоку обізнаність у предметній галузі знань, особистісний досвід суб’єкта, націленого на перспективність у роботі, спрямованої на передачу знань, розвиток сучасного наукового світогляду й особистості учнів, відкритого до динамічного збагачення й самовдосконалення за рахунок отримання, оцінювання інформації та вміння створювати нову, здатного досягати значних результатів і якості в професійній діяльності [6].

Також багато робіт в останні роки присвячено навчанню майбутніх учителів інформатики у ВНЗ України на засадах вільного програмного забезпечення. Цьому аспекту присвятили свої роботи такі науковці, як В. Величко, Ю. Горошко, Л. Панченко, О. Семеріков, І. Теплицький та ін. 
Вільне програмне забезпечення містить у собі чималу кількість важливих, зокрема й стратегічних переваг, серед яких є можливість упровадження вільного програмного забезпечення, що відбувається, як правило, із паралельним вивченням пропрієтарного програмного забезпечення. Перехід до вільного програмного забезпечення можна здійснити шляхом заміни комерційних програмних засобів вільними аналогами [8], що $є$ особливо значущим для економіки країни. Історія створення й розвитку вільного та відкритого програмного забезпечення надає приклад саморозвитку команд розробників програмного забезпечення, що $\epsilon$ результатом самостійної навчальнопізнавальної діяльності. Так, самоосвітня діяльність у межах вільного та відкритого програмного забезпечення стає прикладом навчально-пізнавальної діяльності [2], тобто безпосередньо веде до підвищення розвитку самоосвітньої компетентності як майбутнього, так і практикуючого вчителя інформатики.

Завдяки впровадженням вільного програмного забезпечення відбувається збереження аудиторного часу, набуття досвіду користування інформаційнокомунікаційними технологіями, активізація пізнавальної діяльності, упровадження нових методик навчання, розкриття творчих та індивідуальних можливостей тих, хто навчається, формування наукового світогляду та інформаційної культури [2, с. 197], а також розвиток навичок нестандартного мислення майбутнього та практикуючого вчителя інформатики.

Упровадження вільного програмного забезпечення відбувається, як правило, із паралельним вивченням пропрієтарного програмного забезпечення. Перехід до вільного програмного забезпечення можна здійснити шляхом заміни комерційних програмних засобів вільними аналогами, що $є$ близькими не лише за виконуваними функціями, а й за інтерфейсом, що дає змогу провести швидкий перехід на вільне програмне забезпечення еволюційним шляхом без втрати набутих раніше загальних методів і прийомів роботи [3].

Також треба зауважити, що існує багато розроблених методик удосконалення навчання майбутніх учителів інформатики у вищих навчальних закладах (В. Величко, Ю. Горошко, М. Жалдак, Н. Морзе, О. Семеріков, О. Співаковський, О. Спірін, Ю. Тріус та інші ), але, беручи до уваги постійні зміни і покращення техніки та технологій, це питання потребує постійних змін та оновлень. Аналізуючи вищезазначене, бачимо, що вчитель інформатики $\epsilon$ не лише вчителем сьогодення, а й учителем майбутнього, бо технологічний та інформаційний розвиток мають високу прогресію.

Висновки 3 дослідження і перспективи подальших розвідок у цьому напрямі. Отже, можемо констатувати, що актуальність дослідження підвищення ефективності навчального процесу майбутніх учителів інформатики, орієнтованих на розвиток особистості майбутніх фахівців, є дуже насущною, особливо в руслі стрімкої інформатизації суспільства. Задля вдосконаленні розвитку будь-яких компетенцій та компетентностей доцільними методами можуть слугувати не лише читання та вивчення навчальної літератури, а й 
повсякденне та різноманітне використання інформаційно-комунікаційних технологій, програмного забезпечення, яке на сьогодні є у великій кількості як пропрієтарним, так і вільним. Також стало зрозумілим, що на сьогодні немає визначення пріоритетних компетентностей або компетенцій, що сприяють розвитку вчителів інформатики.

Як для майбутнього, так і практикуючого вчителя інформатики розвиток компетентностей та компетенцій таких, як, наприклад, професійна компетентність, інформатична компетентність, спеціальна та предметна компетентності, професійно-методична компетентність, соціальнокомунікативна компетентність, загальна компетентність, особистісно орієнтована компетентність та багато інших є запорукою власного розвитку. Оволодіння різноманітними компетентностями та компетенціями призведе до формування високого рівня власної освітньої траєкторії, що насамперед надасть мотиваційне підгрунтя для створення можливостей досягнення багаторівневих i різноманітних знань, базуючись на власне сформованому індивідуальному підході набуття знань, умінь, навичок, використовуючи як традиційні, так і будьякі сучасні методи і методики навчання. Також перспективним $\epsilon$ всебічний розгляд різноманітних форм програмного забезпечення як пропрієтарного, так $\mathrm{i}$ вільного $з$ подальшим визначенням і уточненням важливості переходу на програмні продукти ВПЗ у роботах як аспірантів, докторантів, так і сучасних науковців і дослідників.

\section{СПИСОК ВИКОРИСТАНИХ ДЖЕРЕЛ}

1. Величко, В. С. (2016). Педагогічні умови використання вільного та відкритого програмного забезпечення при підготовці вчителів математики, фізики та інформатики. Електронне наукове фахове видання «Науковий вісник Донбасу», 1-2 (33-34). Взято 3 http://nvd.luguniv.edu.ua/archiv/2016/N1-2(33-34)/6.PDF

2. Величко, В. С. (2017). Теоретико-методичні засади застосування вільного програмного забезпечення у підготовці майбутніх учителів математики, фізики та інформатики. Слов'янськ, Україна: Вид-во Б. І. Маторін.

3. Горошко, Ю. В., Костюченко, А. О. і Шкардибарда, М. І. (2010). Проблеми та особливості впровадження вільного програмного забезпечення в навчальний процес. Комп'ютер у школі та сім'ї, 7, 8-10.

4. Захар, О. Г. (2015). ІК-компетентність вчителя інформатики та шляхи іiі формування. Open educational e-environment of modern University, 1, 21-32. Взято 3 http://openedu.kubg.edu.ua/journal/index.php/openedu/article/view/3/3\#.WwLXMTSFPIU

5. Зязюн, І. А. (2000). Педагогіка добра: ідеали і реалії. Київ, Україна: МАУП.

6. Котенко, В. В. и Сурменко, С. Л. (2006). Информационно-компьютерная компетентность как компонент профессиональной подготовки будущего учителя информатики. Вестник Омского государственного педагогического университета. Взято с http://www.omsk.edu/article/vestnik-omgpu-114.pdf.

7. Пометун, О. (2005). Компетентнісний підхід - найважливіший орієнтир сучасної освіти. Рідна школа, 1, 65-69.

8. Семеріков, С. О. і Теплицький, І. О. (2003). 3 досвіду використання вільного програмного забезпечення у підготовці майбутнього вчителя. Рідна школа, 5, 40-41. 
9. Семеріков, С. О. (2009). Теоретико-методичні основи фундаменталізації навчання інформатичних дисциплін у вищих навчальних закладах. (Дис. д-ра пед. наук). Київ, Україна: НПУ ім. М. П. Драгоманова.

10. Сергієнко, В. і Войтович, I. (2013). Удосконалення соціально орієнтованої технічної підготовки майбутніх учителів інформатики. Наукові записки. Педагогічні науки, $121(2), 8-12$.

11. Скоробогатова, Т. С. (2011). Развитие самообразовательной компетентности у будущего учителя информатики. Педагогическое образование в России, 206-210.

12. Спірін, О. М. (2009). Інформаційно-комунікаційні та інформатичні компетентності як компоненти системи професійно-спеціалізованих компетентностей вчителя інформатики. Інформачійні технології $i$ засоби навчання, 5 (13). Взято 3 https://journal.iitta.gov.ua/index.php/itlt/article/view/183/169

13. Спірін, О. М. (2007). Компетентнісний підхід у проектуванні професійної підготовки вчителя інформатики. Науковий часопис НПУ імені М.П.Драгоманова, 5 (7), $150-156$.

14. Федоренко, О. Г. (2016). Формування самоосвітньої компетентності майбутніх учителів технологій засобами інформаційно-комунікаиійних технологій. (Дис. канд. пед. наук). Слов'янськ, Україна: ДВНЗ «ДДПУ».

15. Шамало, Т. Н. и Александрова, Н. В. (2007). Формирование информационной компетенции будущих учителей. Образование и наука, 5, 63-69.

\title{
ПОПЫТКА АНАЛИЗА ЗАИНТЕРЕСОВАННОСТИ УЧЕНЫХ И ИССЛЕДОВАТЕЛЕЙ ВО ВСЕСТОРОННЕМ РАЗВИТИИ БУДУЩИХ И ПРАКТИКУЮЩИХ УЧИТЕЛЕЙ ІНФОРМАТИКИ
}

\author{
Елена Федоренко \\ кандидат педагогических наук, доцент кафедры \\ методики обучения математики и методики обучения информатики, \\ ГВУЗ «Донбасский государственный педагогический университет» \\ г. Славянск, Донецкая область, Украина \\ http://orcid.org/0000-0002-1897-874X \\ fedorenko.elena1209@gmail.com \\ Анна Зима \\ учитель информатики I категории \\ заместитель директора по научно-методической работе \\ Райгородокская ООШ I-III ступеней \\ Донецкая область, Славянский район, пгт. Райгородок, \\ http://orcid.org/0000-0002-0525-6553 \\ raygorodokuspih@i.ua
}

\begin{abstract}
Аннотация. Статья посвящена анализу проблем всестороннего развития будущих и практикующих учителей информатики. Анализируя работы современных ученых и исследователей, был выявлен большой ряд рассматриваемых проблем и разработанных ними методик и методических рекомендаций, связанных со всесторонним развитием будущих и практикующих учителей информатики. Положительным и прогрессивным моментом является то, что для всестороннего развития будущих и практикующих учителей информатики разработано большое количество методик и методических рекомендаций, связанных с
\end{abstract}


повышением различных компетенций и компетентностей, основанных на информационнокоммуникационных технологиях и современном программном обеспечении как проприетарном, так и свободном. Подчеркивается, что информационно-коммуникационные технологии являются базисом развития личности с профессиональной точки зрения, они служат основой развития индивидуальных, творческих способностей, а также личных качеств таких, как саморазвитие и самореализация.

Ключевые слова: компетенция; компетентность; будущие учителя информатики; практикующие учителя информатики; проприетарное программное обеспечение; свободное программное обеспечение.

\title{
ATTEMPT TO ANALYSE INTEREST OF SCIENTISTS AND RESEARCHERS IN THE COMPREHENSIVE DEVELOPMENT OF FUTURE AND PRACTICING COMPUTER STUDIES TEACHERS
}

\author{
Olena Fedorenko \\ Candidate of Pedagogical Sciences, \\ Associate Professor of the Department of Methods of Teaching Mathematics and \\ Methods of Teaching Computer Studies, \\ SHEE «Donbas State Pedagogical University» \\ Sloviansk, Donetsk region, Ukraine \\ http://orcid.org/0000-0002-1897-874X \\ fedorenko.elena1209@gmail.com \\ Hanna Zyma \\ Computer Studies Teacher \\ Vice Principal in Learning and Methodological Work \\ Raihorodok Comprehensive School of I-III levels \\ Raihorodok, Donetsk region, Ukraine \\ http://orcid.org/0000-0002-0525-6553 \\ raygorodokuspih@i.ua
}

\begin{abstract}
The article is devoted to the analysis of problems of comprehensive development of future and practicing teachers of Computer Studies considered by scientists and researchers. By analyzing the work of modern scientists and researchers, a large number of problems, methods and methodological recommendations developed by them were identified, connected with the comprehensive development of future and practicing teachers of Computer Studies. It was a positive and progressive moment that a large number of methodologies and methodological recommendations were developed for the comprehensive development of future and practicing teachers of Computer Studies related to the increase of various competences and competences based on information and communication technologies and modern software, both proprietary and free. It is emphasized that information and communication technologies are the basis for personal development both from the professional point of view, serving as a basis for developing individual and creative abilities, and from the view point of developing personal qualities such as self-development and self-realization.

Based on the aspects of global informatization of society, we have found that the development of skills for constant self-improvement and self-realization for both future and practicing Computer Studies teachers should be the basis of modern higher education. A number of problems are considered by scientists and researchers concerning the development of Computer Studies teachers,
\end{abstract}


their professional, self-education, informational competences, the development of which is of great importance for teachers of Computer Studies both future ones and practitioners.

An attempt was made to analyze the interest of modern researchers in developing a wide range of methodologies and methodological recommendations intended for the comprehensive development of Computer Studies teachers.

The main features of modern specialists who are intended to achieve a high level of their own professionalism are revealed. The general and professional-specialized competences of future and practicing Computer Studies teachers are singled out and their components are listed. It is noted that modern teachers of Computer Studies are the main link between informatization of society and younger generations.

It is noted that at present, many works of researchers and scientists are devoted to the problems of the introduction of free software into training activities of future Computer Studies teachers. This software allows to update software resources to more modern, but do not spend money on the purchase of new software products or updates. The advantages of such implementations, their accessibility both in the financial aspect and in the aspect of intellectual understanding of the indicated software are underlined. The conclusions emphasized on the relevance of this study, and identified methods for improving the personal growth of future and practicing teachers of Computer Studies. Listed competences, which a modern teacher of Computer Studies should master, indicate the prospects for further exploration.

Key words: competence; future teachers of Computer Studies; practicing Computer Studies teachers; proprietary software; free software.

\section{REFERENCES}

1. Velychko, V. Ye. (2016). Pedagogical Conditions of Use of Free and Open Source Software in the Preparation of Teachers of Mathematics, Physics and Computer Science. Elektronne naukove fakhove vydannia 'Naukovyi visnyk Donbasu', 1-2 (33-34). Retrieved from http://nvd.luguniv.edu.ua/archiv/2016/N1-2(33-34)/6.PDF

2. Velychko, V. Ye. (2017). Theoretical and methodical principles of the use of free software in the training of future teachers of mathematics, physics and computer science. Sloviansk, Ukraine: Vyd-vo B. I. Matorin.

3. Horoshko, Yu. V., Kostiuchenko, A. O., \& Shkardybarda, M. I. (2010). Problems and peculiarities of the introduction of free software into the educational process. Kompiuter u shkoli ta simi, 7, 8-10.

4. Zakhar, O.H. (2015). ICT-competence of computer science teachers and ways of formation. Open educational e-environment of modern University, 1, 21-32. Retrieved from http://openedu.kubg.edu.ua/journal/index.php/openedu/article/view/3/3\#.WwLXMTSFPIU MAUP.

5. Ziaziun, I. A. (2000). Pedagogy of Goodness: Ideals and Realities. Kyiv, Ukraine:

6. Kotenko, V. V., \& Surmenko, S. L. (2006). Information-computer competence as the component of professional training of the future teacher of the information science. Vestnik Omskogo gosudarstvennogo pedagogicheskogo universiteta. Retrieved from http://www.omsk.edu/article/vestnik-omgpu-114.pdf

7. Pometun, O. (2005). The Competence Approach is the Most Important Landmark of Modern Education. Ridna shkola, 1, 65-69.

8. Semerikov, S. O., \& Teplytskyi, I. O. (2003). The experience of the use of Free Software in training future teachers. Ridna shkola, 5, 40-41.

9. Semerikov, S. O. (2009). Theoretical and methodic foundations of fundamentalization teaching of the Computer Science at the high educational institutions. (Doctoral dissertation). Kyiv, Ukraine: NPU im. M. P. Drahomanova.

Професіоналізм педагога: теоретичні й методичні аспекти. - Вип. 7. - Слов’янськ, 2018. 
10. Serhiienko, V., \& Voitovych, I. (2013). Improvement of socially oriented technical training of future teachers of computer science. Naukovi zapysky. Pedahohichni nauky, 121 (2), 8-12.

11. Skorobogatova, T. S. (2011). Development of self education competence of future computer science teacher. Pedagogicheskoe obrazovanie v Rossii, 4, 206-210.

12. Spirin, O. M. (2009). Information and communication and informatic competences as komponents of the system of professional-specialized competences of informatics teacher. Informatsiini tekhnolohii $i$ zasoby navchannia, 5 (13). Retrieved from https://journal.iitta.gov.ua/index.php/itlt/article/view/183/169

13. Spirin, O. M. (2007). Competent approach in the design of computer science teacher training. Naukovyi chasopys NPU imeni M.P.Drahomanova, 5 (7), 150-156.

14. Fedorenko, O. H. (2016). Formation of self-educational competence of future teachers of technology tools ICT. (PhD dissertation). Sloviansk, Ukraine: DVNZ "DDPU".

15. Shamalo, T. N., \& Aleksandrova, N. V. (2007). Formation of the information competence of future teachers. Obrazovanie i nauka, 5, 63-69.

Матеріали надійшли до редакції 28.03.2018 р. 